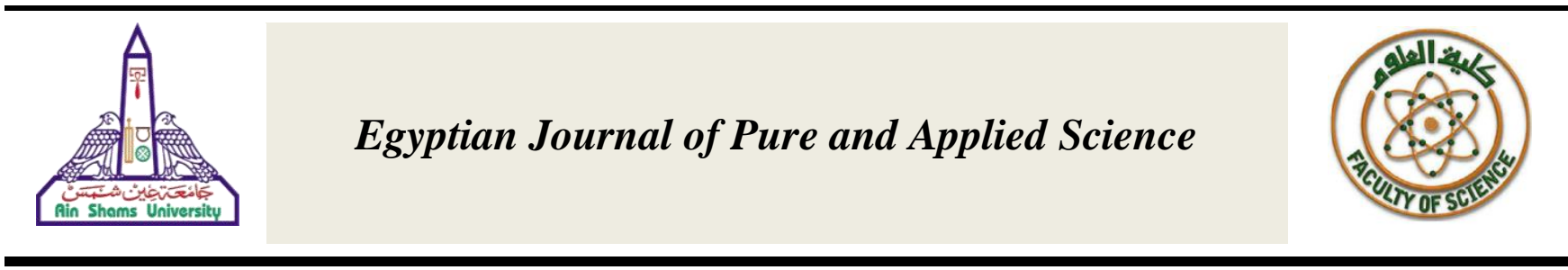

\title{
Evaluation of the antitumor effects of gallium trichloride and doxorubicin in cancer treatment
}

\author{
Eman Kandil*
}

Department of Biochemistry, Faculty of Science, Ain Shams University, Abbassia 11566, Cairo, Egypt.

\section{A R T I C L E I N F O}

Article history:

Accepted 14 March 2016

Keywords:

Ehrlich carcinoma;

Doxorubicin;

Gallium trichloride;

Cardiomyopathy.
Received 16 February 2016

\begin{abstract}
A B S T R A C T
Traditional cancer therapy can be successful in destroying tumors, but can also cause detrimental side effects. Doxorubicin (Dox) is a potent antitumor agent whose activity is severely limited by a cumulative dose-dependent chronic cardiotoxicity. Therefore, combination chemotherapy is considered to be the backbone of cancer treatment. Thus, the aim of the present study was to investigate the antitumor effect of gallium trichloride $\left(\mathrm{GaCl}_{3}\right)$ and to evaluate the possible role of combination of $\mathrm{GaCl} 3$ with Dox fractionated dose in reducing cardiac injury. Gallium trichloride (300 mg/kg b.w./day) was orally administered daily during 3 weeks either alone or combined with (Dox) that administered intraperitoneally ( $4 \mathrm{mg} / \mathrm{kg}$ b.w./day) once a week for 3 weeks, in solid Ehrlich carcinoma (EC) bearing mice. Biochemical analysis as well as histopathological examination were performed. The results demonstrate that 3-weeks course of sequential administration of $\mathrm{GaCl}_{3}$ either alone or combined with Dox leads to substantial inhibition of tumor growth, enhancement of antioxidant enzymes activity, induction of apoptosis. These findings were well appreciated by the histopathological examination of solid tumor in the treated groups. It could be concluded that $\mathrm{GaCl}_{3}$ may be a useful synergistic chemotherapeutic agent with other anticancer drugs. Further studies should be done to ascertain these findings on clinical level.
\end{abstract}
Introduction
Cancer has become a hot topic in medicine since it is a major cause of death in both the developed and developing countries and it is now only secondary to that of myocardial infarction ${ }^{[1]}$. The most effective antitumor treatment is currently achieved by chemotherapeutic agents that abrogate tumor cells, but can also cause dangerous side effects, in that they don't only affect the proliferated cells, but also the normal cells ${ }^{[2]}$. With this in mind, novel strategies for treating malignancies are being developed on the experimental level in order to be applied in clinical setting.
The anticancer drug (Dox) has been widely used for the treatment of a broad spectrum of cancers ${ }^{[3]}$. A major adverse side effect associated with Dox usage is the onset of cardiomyopathy and heart failure. Several reports suggest that Dox-induced apoptosis in endothelial cells plays an important role in its cardiotoxicity that is linked to formation of reactive oxygen species (ROS) derived from redox activation of Dox ${ }^{[4,5]}$. Recent studies have focused on Dox-induced
* Corresponding author.
E-mail address: kandil.eman@yahoo.com
apoptotic signaling mechanisms ${ }^{[6]}$.
Over the past two to three decades, gallium compounds have gained importance in the fields of medicine and electronics ${ }^{[7]}$. Gallium, a metal from group 13 (IIIa) of the periodic table, has been reported to be active against various tumor cells, both in vitro and in vivo ${ }^{[8-10]}$. In clinical medicine, radioactive gallium and stable gallium nitrate are used as diagnostic and therapeutic agents in cancer treatment. Gallium (III) and subsequently developed gallium (III)-containing complexes have shown promising antineoplastic effects when tested in a host of malignancies, specifically in lymphomas and bladder cancer. However, the molecular mechanism responsible for their anticancer effect is yet to be fully understood. Foster et al. ${ }^{[9]}$ cited at least five reasons to continue evaluating this antitumor candidate: (a) it has been shown to concentrate in human tumors; (b) it has a broad spectrum of preclinical activity in massive solid tumors; (c) it does not produce significant myelosuppression in humans making it an attractive candidate for combination chemotherapy; (d) the risk of renal toxicity can be reduced by $30 \%$ according to mode of drug delivery, without impairing antitumor activity 
and (e) it has exhibited clinical antitumor activity especially in patients with refractory lymphomas and cancer related hypercalcemia.

The anti-proliferative mechanism of gallium action could be related to its competition with iron atom from the circulation, thus causing disruption of normal cellular iron homeostasis ${ }^{111}$. It modifies threedimensional structure of DNA and inhibits its synthesis, modulates protein synthesis; also, it inhibits the activity of a number of enzymes, such as ATPases, DNA polymerases, ribonucleotide reductase and tyrosine specific protein phosphatase. It is worth mentioning that $\mathrm{Ga}$ salts are taken up more efficiently and more specifically by tumor cells when gavage orally ${ }^{[12]}$. Moreover, scientists tended to combine gallium salts with other chemotherapeutic drugs hoping that this will improve the results of the treatment ${ }^{[13]}$.

The application of gallium in clinical medicine may be advanced by a better understanding of their mechanisms of action, drug resistance, pharmacology, clinical efficacy, and potential side-effects of gallium compounds as drugs.

The present study had two objectives. The first was to investigate the antitumor effect of gallium trichloride against Solid Ehrlich carcinoma induced in mice. The second objective was to evaluate the coadministration of gallium trichloride with doxorubicin (Dox) to reduce the adverse effect associated with Dox usage such as heart failure in vivo.

\section{Materials and Methods}

\section{Chemicals}

Gallium trichloride, product no. G450898, was purchased from Sigma-Aldrich company, dissolved in water. Seven days after tumor transplantation, every mouse was orally supplemented by $300 \mathrm{mg} / \mathrm{kg}$ b.w./day daily for 3 weeks.

Doxorubicin hydrochloride, available commercially as Adriblastina $^{\circledR}$ (Pharmacia, Italy), was provided as a stock solution $(10 \mathrm{mg} / 5 \mathrm{ml}(\mathrm{HCl}))$. Seven days after tumor transplantation, every mouse was i.p. injected by $4 \mathrm{mg} / \mathrm{kg}$ b.w. /day once a week for 3 weeks.

\section{Animals}

Adult female Swiss albino mice weighing 22-25g purchased from the breeding unit of the Egyptian Organization for Biological Products and Vaccines (Cairo) were used in this study. The animals were maintained on a commercial standard pellet diet and tap water ad libitum. Animal maintenance and treatments were conducted in accordance with the National Institute of Health Guide for Animal, as approved by Institutional Animal Care and Use Committee (IACUC).

\section{Tumor Transplantation}

A cell line of Ehrlich Ascites Carcinoma (EAC) was used in this study. The parent line was supplied from Egyptian National Cancer Institute (NCI), Cairo University. The tumor cell line was transplanted in the experimental female Swiss albino mice by weekly intraperitoneal injection of 2.5 million cells per mouse until the end of the experiment. The EAC cells were counted before intraperitoneal injection using the bright line (hemocytometer) and dilution was done using physiological sterile saline solution. The desired numbers of cells were injected in a volume of $0.2 \mathrm{ml}$. To achieve Ehrlich Solid Tumor, $0.2 \mathrm{ml}$ EAC cells $(2.5 \mathrm{x}$ $10^{6}$ cells/mouse) were inoculated intramuscularly in the right thigh of the lower limb of female mice.

\section{Determination of $\mathrm{LD}_{\mathbf{5 0}}$ using experimental animals}

In screening drugs, determination of $\mathrm{LD}_{50}$ (the dose which has proved to be lethal to $50 \%$ of the tested group of animals) is usually an initial step in the assessment and evaluation of the toxic characteristics of a substance. It is an initial assessment of toxic manifestations (provides information on health hazards likely to arise from short-term exposure to drugs) and is one of the initial screening experiments performed with all compounds [14]. The studied compounds were administered orally in graduated doses and $\mathrm{LD}_{50}$ were determined ${ }^{[15]}$. The optimum selected dose for evaluating the in vivo antitumor activity of the tested compounds was calculated approximately as (1/10) of its $\mathrm{LD}_{50}$ value.

\section{Experimental design}

Sixty animals were randomly divided into five equal groups as follows:

Group (1): Normal healthy control animals.

Group (2): Ehrlich Ascites Carcinoma inoculated mice (EC): Animals were inoculated intramuscularly in the right thigh by $2.5 \times 10^{6}$ Ehrlich Ascites Carcinoma cells.

Group (3): EC bearing mice were treated i.p. with Dox (4 $\mathrm{mg} / \mathrm{kg} /$ day) once a week for 3 weeks.

Group (4): EC bearing mice were gavage with proper dose of $\mathrm{GaCl}_{3}(300 \mathrm{mg} / \mathrm{kg} /$ day $)$ daily for 3 weeks.

Group (5): EC bearing mice were i.p. injected with Dox as described in group (3) followed by gavage with proper dose of $\mathrm{GaCl}_{3}$ as described in group (4).

\section{Tumor volume monitoring}

The change in tumor volume was measured regularly twice weekly using Vernier calipers and calculated by the following formula: Tumor volume $\left(\mathrm{mm}^{3}\right)=4 \pi \mathrm{A}^{2} \mathrm{~B}$, where $A$ is the major axis and $B$ is the minor axis ${ }^{[16]}$.

\section{Blood collection and tissue sampling}

Two days after the last treatment in each group, the animals were weighed and dissected under light ether anesthesia. Blood samples were collected and centrifuged to separate serum. Serum was separated for the un-delayed analysis of total creatine phosphokinase (CPK), aspartate aminotransferase (AST) and lactate dehydrogenase (LDH) activities. At autopsy, animals were thoractomized, tumors and the hearts were excised and parts of tumors and whole hearts were kept in a plastic vial containing sterile saline at $-20^{\circ} \mathrm{C}$ until biochemical analysis, while the other parts of tumors were fixed in $10 \%$ formalin for histological examination.

\section{Preparation of tissue homogenate}

The heart and parts of tumor tissues were homogenized 
in ice-cold $50 \mathrm{mM}$ Tris- $\mathrm{HCl} / 0.25 \mathrm{M}$ sucrose buffer $(\mathrm{pH}$ 7.4) to prepare $\mathrm{a} 10 \%(\mathrm{w} / \mathrm{v})$ tissue homogenate for determination of malondialdehyde content, glutathione peroxidase and catalase activities. An aliquot of the whole tissue homogenate was centrifuged at 10,000 rpm for $15 \mathrm{~min}$ at $4^{\circ} \mathrm{C}$ and the cytosolic supernatant was used for the determination of inflammatory cytokines, interleukin-10 and tumor necrosis factor-alpha.

\section{Biochemical parameters}

Serum total CPK and LDH activities were measured according to Rosalki ${ }^{[17]}$ for CPK and Buhl \& Jackson ${ }^{[18]}$ for LDH by the kinetic method using commercial assay kits (Stanbio, USA). Serum AST activity was measured colorimetrically by the method of Reitman \& Frankel ${ }^{[19]}$ using a commercial assay kit (QCA, Spain). Iron concentration was determined in serum according to Dreux ${ }^{[20]}$. Lipid peroxide concentrations were determined in heart and tumor tissues by measuring the malonaldialdahyde (MDA) end product as described by Yoshioka et al. ${ }^{[21]}$. The glutathione peroxidase (Gpx) and catalase (CAT) activities ware assayed in heart and tumor tissues by using colorimetric assay for cellular glutathione peroxidase ${ }^{[22]}$ and spectrophotometric assay for catalase ${ }^{[23]}$, respectively. Heart and tumor tissues homogenate of each group was assayed for TNF-alpha level using mouse TNF-alpha ELISA kit purchased from KOMA Biotech Inc. (South Korea) catalog no. K0331186. IL-10 was determined in heart and tumor tissues homogenate using mouse IL-10 platinum ELISA kit purchased from Bioscience company (USA) catalog no. BMS614/2.

\section{Histopathological examination}

After fixation of tumor tissues in formalin (10\%) for 24 hours, certain steps were performed to get the paraffin blocks. Sections of 5 microns thickness were cut and stained with (hematoxylin) and eosin (24) and examined by light microscope for histopathological investigation.

\section{Statistical analysis}

All values are reported as the mean \pm SE. Data were analyzed using a one-way analysis of variance (ANOVA). The level of significance between mean values was set at $\mathrm{P} \leq 0.05$. All statistical analyses were performed using SPSS software (Version 20.0).

\section{Results}

\section{Tumor volume}

EC size monitoring is illustrated as shown in Figure 1. It is clear that the inoculation of 2.5 million of EC cells in the thigh region of healthy normal female mice produced a tumor with a mean size of $723.6 \pm 6.7 \mathrm{~mm}^{3}$ on the $10^{\text {th }}$ day after tumor inoculation. EC size proceeded by days reaching $2805 \pm 10.5 \mathrm{~mm}^{3}$ on the 21 days after tumor inoculation. Gavages of the experimental animals with $\mathrm{GaCl}_{3}$ and/or Dox 7 days after EC tumor cell inoculation caused a marked suppression of tumor growth where the tumor volume was significantly decreased compared to corresponding EC group. Also, groups of animals treated with $\mathrm{EC}+\mathrm{GaCl}_{3}$ or $\mathrm{EC}+\mathrm{Dox}+\mathrm{GaCl}_{3}$ showed suppression of tumor volume when compared with EC+Dox group.

\section{Biochemical analysis}

The results obtained in the present study revealed that the inoculation of EC in mice induced a significant decrease in catalase and glutathione peroxidase activities accompanied with a significant increase in MDA content in heart tissue compared to their corresponding control values $(p<0.05)$. Treatment of animal bearing tumor with $\mathrm{GaCl}_{3}$ and /or Dox induced a significant increase in antioxidant activities (CAT \& GPx) with a normalization of MDA in the other three treated groups compared to tumor group (Table1). There was a significant decrease in MDA level accompanied with a significant increase in GPx activity in groups of animals treated with $\mathrm{EC}+\mathrm{GaCl}_{3}$ and $\mathrm{EC}+\mathrm{Dox}+\mathrm{GaCl}_{3}$ compared to $\mathrm{EC}+$ Dox group.

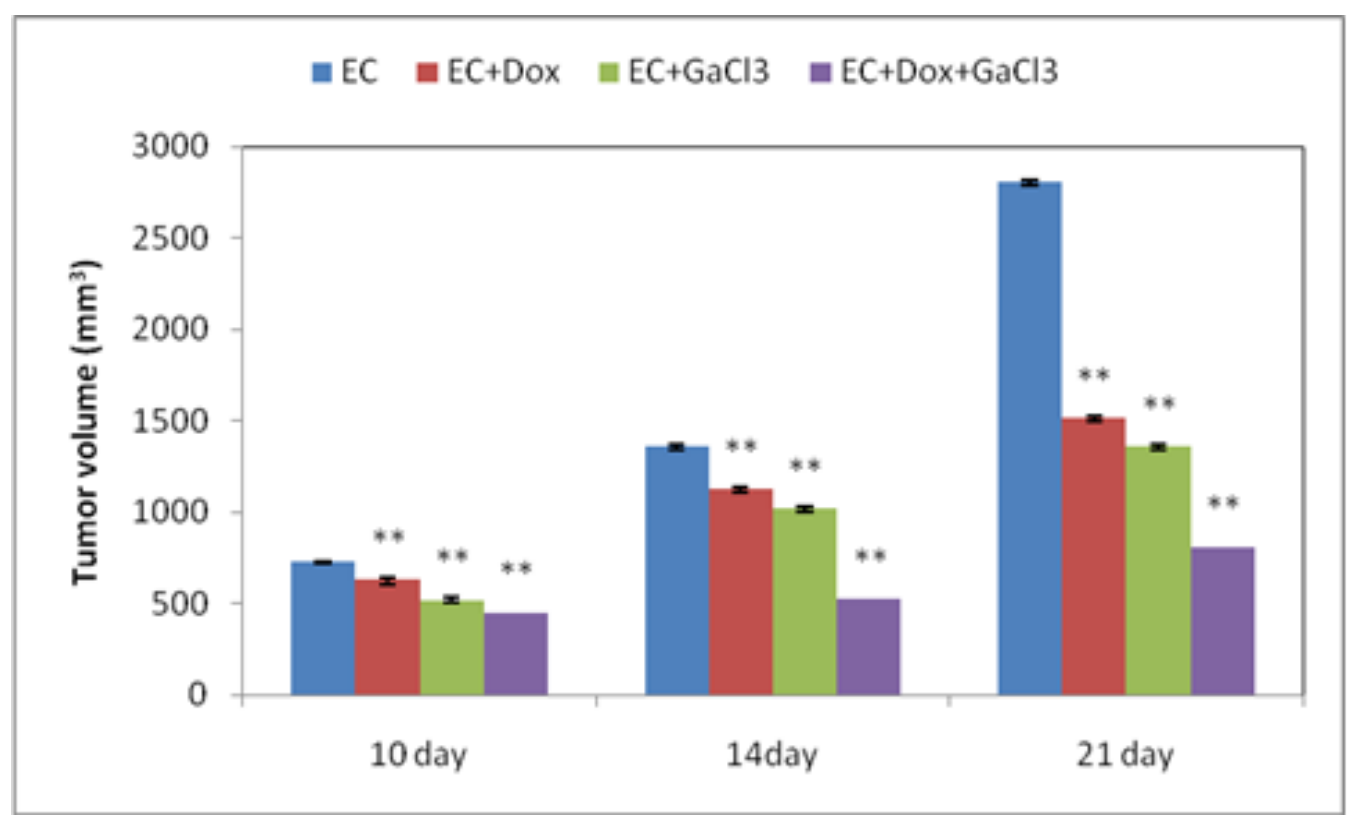

Figure (1): Effects of gallium trichloride and/or doxorubicin (DOX) on tumor volume $\mathrm{mm}^{3}$ of EC mice bearing tumor. **: significant to EC 
Table 1: Effects of gallium trichloride and/or doxorubicin on the level of malondialdehyde (MDA), catalase (CAT) and glutathione peroxidase (GPx) in heart tissues of EC bearing mice.

\begin{tabular}{|l|l|l|l|}
\hline Groups & Parameters & Catalase $(\mathbf{U} / \mathbf{g})$ & $\mathbf{G P}_{\mathbf{X}}(\mathbf{m U} / \mathbf{g})$ \\
\hline Control & $249.6 \pm 8.7^{\mathrm{bc}}$ & $48.3 \pm 1.5^{\mathrm{bcde}}$ & $436.4 \pm 9.2^{\mathrm{bcde}}$ \\
\hline $\mathbf{E C}$ & $316.6 \pm 8.8^{\mathrm{acde}}$ & $23.0 \pm 1.7^{\mathrm{acde}}$ & $128.8 \pm 5.1^{\mathrm{acde}}$ \\
\hline $\mathbf{E C}+\mathbf{D o x}$ & $289.5 \pm 8.1^{\mathrm{ade}}$ & $32.6 \pm 1.8^{\mathrm{ab}}$ & $256.7 \pm 9.5^{\mathrm{abde}}$ \\
\hline $\mathbf{E C}+\mathbf{G a C l}_{\mathbf{3}}$ & $253.1 \pm 7.4^{\mathrm{bc}}$ & $38.3 \pm 2.6^{\mathrm{ab}}$ & $342.2 \pm 6.6^{\mathrm{abc}}$ \\
\hline $\mathbf{E C}+\mathbf{D o x}+\mathbf{G a C l}_{\mathbf{3}}$ & $253.9 \pm 7.8^{\mathrm{bc}}$ & $38.0 \pm 2.3^{\mathrm{ab}}$ & $359.4 \pm 8.0^{\mathrm{abc}}$ \\
\hline
\end{tabular}

Each value represents mean \pm SE. of eight values. ${ }^{a}$ Significance vs control group; ${ }^{b}$ Significance vs EC group; ${ }^{c}$ Significance vs

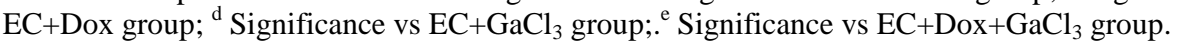

The results presented in tumor tissue in Table $\mathbf{2}$ showed that the treatment of EC bearing mice with $\mathrm{GaCl}_{3}$ and/or Dox caused a significant increase in the level of MDA, while the levels of catalase and glutathione peroxidase in tumor tissue were significantly decreased $(\mathrm{p}<0.05)$ compared to their respective levels in EC tumor group. More pronounced increase in GPx activity was detected in group of animals treated with $\mathrm{EC}+\mathrm{GaCl}_{3}$ in comparison with other treated groups.

Data presented in Table $\mathbf{3}$ showed a significant elevation in serum AST, CPK and LDH activities in EC and $\mathrm{EC}+$ Dox groups in comparison with those of controls. Administration of $\mathrm{GaCl}_{3}$ alone or combined with Dox significantly ameliorated the results close to normal control. A significant decrease in serum AST, $\mathrm{CPK}$ and $\mathrm{LDH}$ activities was observed in each of $\mathrm{EC}+\mathrm{GaCl}_{3}$ and $\mathrm{EC}+\mathrm{Dox}+\mathrm{GaCl}_{3}$ groups compared with $\mathrm{EC}+$ Dox group. Serum iron concentration decreased significantly $(\mathrm{p}<0.05)$ in all studied groups compared to control group, this decrease is more pronounced in tumor group treated with $\mathrm{GaCl}_{3}$ and Dox. An elevation was observed in a group of animals treated with Dox compared to EC group.

Table 2: Effects of gallium trichloride and/or doxorubicin on the level of malondialdehyde (MDA), catalase (CAT) and glutathione peroxidase (GPx) in tumor tissues of EC bearing mice.

\begin{tabular}{|l|l|l|l|}
\hline Groups & Marameters & Catalase $(\mathbf{U} / \mathbf{g})$ & $\mathbf{G P}_{\mathbf{X}}(\mathbf{m U} / \mathbf{g})$ \\
\hline $\mathbf{E C}$ & $95.3 \pm 5.7^{\mathrm{bcd}}$ & $36.7 \pm 1.6^{\mathrm{bcd}}$ & $384.6 \pm 10.0^{\mathrm{bcd}}$ \\
\hline $\mathbf{E C}+\mathbf{D o x}$ & $139.1 \pm 8.0^{\mathrm{a}}$ & $27.1 \pm 2.3^{\mathrm{a}}$ & $256.8 \pm 9.53^{\mathrm{ac}}$ \\
\hline $\mathbf{E C}+\mathbf{G a C l}_{\mathbf{3}}$ & $125.0 \pm 7.5^{\mathrm{a}}$ & $28.5 \pm 1.1^{\mathrm{a}}$ & $350.0 \pm 8.6^{\mathrm{abd}}$ \\
\hline $\mathbf{E C}+\mathbf{D o x}+\mathbf{G a C l}_{\mathbf{3}}$ & $130.0 \pm 9.7^{\mathrm{a}}$ & $27.4 \pm 1.2^{\mathrm{a}}$ & $231.1 \pm 6.3^{\mathrm{ac}}$ \\
\hline
\end{tabular}

Each value represents mean \pm SE. of eight values. ${ }^{a}$ Significance vs EC group; ${ }^{b}$ Significance vs EC+Dox group; ${ }^{c}$ Significance vs $\mathrm{EC}+\mathrm{GaCl}_{3}$ group; d Significance vs $\mathrm{EC}+\mathrm{Dox}+\mathrm{GaCl}_{3}$ group.

Table 3: Effects of gallium trichloride and/or doxorubicin on serum aspartate aminotransferase, (AST), creatine phosphokinase (CPK), and lactate dehydrogenase (LDH) activities and iron levels of EC bearing mice.

\begin{tabular}{|c|c|c|c|c|}
\hline $\begin{array}{ll}\text { Groups } & \text { Parameters }\end{array}$ & AST (U/L) & CPK (U/L) & LDH (U/L) & Iron $(\mu \mathrm{mol} / \mathrm{L})$ \\
\hline Control & $435.3 \pm 8.6^{b c}$ & $214.4 \pm 8.3^{\mathrm{bc}}$ & $624.7 \pm 8.6^{\mathrm{bc}}$ & $144.3 \pm 8.6^{\text {bde }}$ \\
\hline EC & $603.0 \pm 26.2^{\text {acde }}$ & $549.0 \pm 5.8^{\text {acde }}$ & $749.5 \pm 11.2^{\text {acde }}$ & $117.7 \pm 7.2^{\text {ade }}$ \\
\hline EC + Dox & $520.0 \pm 8.6^{\text {abde }}$ & $425.7 \pm 6.2^{\text {abde }}$ & $702.5 \pm 10.9^{\text {abde }}$ & $126.3 \pm 5.9^{\mathrm{de}}$ \\
\hline $\mathbf{E C}+\mathrm{GaCl}_{3}$ & $447.7 \pm 8.4^{\mathrm{bc}}$ & $217.8 \pm 10.1^{\mathrm{bc}}$ & $640.0 \pm 11.8^{\mathrm{bc}}$ & $77.0 \pm 5.8^{\mathrm{abc}}$ \\
\hline $\mathrm{EC}+\mathrm{Dox}+\mathrm{GaCl}_{3}$ & $446.0 \pm 9.2^{\mathrm{bc}}$ & $226.4 \pm 7.7^{\mathrm{bc}}$ & $645.7 \pm 9.0^{\mathrm{bc}}$ & $71.2 \pm 6.2^{\mathrm{abc}}$ \\
\hline
\end{tabular}

Each value represents mean \pm SE. of eight values. ${ }^{a}$ Significance vs control group; ${ }^{b}$ Significance vs EC group; ${ }^{c}$ Significance vs

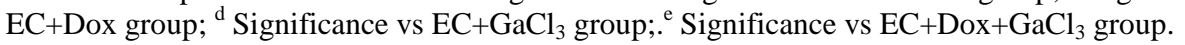


Data shown in table 4 revealed a significant increase in heart and tumor TNF-alpha (TNF- $\alpha$ ) in mice tissue under different treatment conditions compared to EC group and normal control group. The highest TNF- $\alpha$ value in heart tissue was observed in the group of animals treated with EC+Dox as compared with other groups. Interleukin-10 (IL-10) recorded the highest increase in EC+Dox group compared to the other groups.

Table 4: Effects of gallium trichloride and/or doxorubicin on the level of tumor necrosis factor-alpha (TNF- $\alpha)$ and interleukin-10 (IL-10) levels in heart and tumor tissues of EC bearing mice.

\begin{tabular}{|c|c|c|c|c|}
\hline $\begin{array}{ll}\text { Groups } & \text { Parameters } \\
\end{array}$ & $\begin{array}{l}\text { Heart tissue TNF- } \alpha \\
(\mathrm{pg} / \mathrm{g})\end{array}$ & $\begin{array}{l}\text { Tumor tissue TNF- } \\
\alpha(\mathrm{pg} / \mathrm{g})\end{array}$ & $\begin{array}{l}\text { Heart tissue } \\
\text { IL-10 }(\mathrm{pg} / \mathrm{g})\end{array}$ & $\begin{array}{l}\text { Tumor tissue } \\
\text { IL-10 (pg/g) }\end{array}$ \\
\hline Control & $129.5 \pm 5.4^{\text {bcde }}$ & $\ldots \ldots$ & $233.0 \pm 4.7^{\text {bcde }}$ & $\ldots$ \\
\hline EC & $249.1 \pm 5.7^{\text {acde }}$ & $155.0 \pm 5.7^{\text {cde }}$ & $310.0 \pm 5.7^{\text {ade }}$ & $14.7 \pm 1.6^{\text {cde }}$ \\
\hline EC+ Dox & $466.3 \pm 9.2^{\text {abde }}$ & $232.2 \pm 5.7^{\text {bde }}$ & $318.3 \pm 4.4^{\text {ade }}$ & $64.6 \pm 3.3^{\text {bde }}$ \\
\hline $\mathrm{EC}+\mathrm{GaCl}_{3}$ & $205.4 \pm 8.6^{\mathrm{abc}}$ & $981.8 \pm 6.0^{\text {bce }}$ & $260.0 \pm 2.8^{\mathrm{abc}}$ & $26.2 \pm 1.7^{\mathrm{bc}}$ \\
\hline $\mathrm{EC}+\mathrm{Dox}+\mathrm{GaCl}_{3}$ & $226.2 \pm 11.1^{\mathrm{abc}}$ & $595.3 \pm 8.6^{\text {bcd }}$ & $270.0 \pm 5.7^{\mathrm{abc}}$ & $32.4 \pm 2.1^{\mathrm{bc}}$ \\
\hline
\end{tabular}

Each value represents mean \pm SE. of eight values. ${ }^{a}$ Significance vs control group; ${ }^{b}$ Significance vs EC group; ${ }^{\mathrm{c}}$ Significance vs $\mathrm{EC}+$ Dox group; ${ }^{\mathrm{d}}$ Significance vs $\mathrm{EC}+\mathrm{GaCl}_{3}$ group; ${ }^{\mathrm{e}}$ Significance vs $\mathrm{EC}+\mathrm{Dox}+\mathrm{GaCl}_{3}$ group.

\section{Histopathological examination}

Histopathological examination of the solid Ehrlich carcinoma (EC) under light microscope showed a group of intact cancer anaplastic cells with criteria of anaplasia were noticed in the subcutaneous tissue and skeletal muscles of EC mice. Tumor cells are mostly spindle in shape and acquire metastasis architecture (Fig. 2a). Treatment of experimental animals bearing EC with doxorubicin showed that, muscle fibers with normal architecture occupy the peripheral contour. On the other hand, Ehrlich tumor patches are mainly located in the central areas. Small profiles of degenerated muscles fibers are located within these tumor foci. Their myofibrils and consequently their striations have disappeared completely. Tumor areas are basically formed of spindle-shaped cells and are intensively invaded with inflammatory cells (Fig. 2b). Treatment of animals bearing EC with gallium trichloride recorded that, Ehrlich tumor lost its central orientation and is disrupted by bundles of muscle fibers with signs of regenerations, as well as many inflammatory cells. Muscle fibers of these central bundles develop myofibril striations, several necrotic regions with pyknotic nuclei domain tumor foci (Fig. 2c). Treatments of animals bearing EC with doxorubicin and gallium trichloride revealed that, muscle fibers with myofibril striations are more obvious in this group. However, several degenerated muscle fibers are also present. Cells lying deeply within the tumor foci are smaller than their more peripheral counterparts. These tumor foci are also rich in necrotic regions and inflammatory cells, and are usually associated with wide areas of adipose tissues (Fig. 2d).

\section{Discussion}

The present study was performed to assess the potential anticancer effect of gallium trichloride $\left(\mathrm{GaCl}_{3}\right)$ as anticancer drug in vivo and also its possible role in reducing cardiac damage induced by fractionated admin- istration of doxorubicin (Dox).

Combination therapy, using agents that target the microenvironment as well as the cancer cells, is common in the treatment of cancer. Herein, 3-weeks course of sequential administration of the cytotoxic drug Dox (4 $\mathrm{mg} / \mathrm{kg})$, combined with the antitumor agent $\mathrm{GaCl}_{3}$ (300 $\mathrm{mg} / \mathrm{kg}$ ), caused substantial inhibition of tumor growth in mice. The more pronounced delay in tumor volume was recorded when experimental animals were treated with $\mathrm{GaCl}_{3}$ and Dox supporting the synergistic effect of such treatment.

How Dox and $\mathrm{GaCl}_{3}$ elicit these combined antitumor effects remains to be established, but the individual mechanism of action of the drugs is well established. Dox is an (anthracycline) that inhibits topoisomerase II and induces DNA double-strand breaks, interferes with DNA unwinding and induces differentiation and generates oxygen-free radicals ${ }^{[25]}$. Therefore Dox induces growth arrest and nonapoptotic cell death accompanied by DNA damage $[26,27]$

The trivalent $\mathrm{Ga}$ cation is capable of inhibiting tumor growth, mainly because of its resemblance to ferric iron. It affects cellular acquisition of iron by binding to transferrin, and it interacts with the iron-dependent enzyme ribonucleotide reductase, deactivating the enzyme through a conformational change resulting in reduced deoxy ribonucleotide triphosphate (dNTP) pools and inhibition of DNA synthesis. The abundance of transferrin receptors and the upregulation of ribonucleotide reductase render tumor cells susceptible to the cytotoxicity of gallium ${ }^{[28]}$.

Oxidative stress and impaired antioxidant system have been proposed as a potential factor involved in the pathophysiology of diverse disease states, including carcinogenesis ${ }^{[29]}$. This study indicates that EC inoculated in female mice have a marked depletion in tissue GPx and CAT activities with a significant increase in lipid peroxidation product (MDA) compared to the control group. These findings are in agreement with the previous studies which reported that EC induces excessive production 


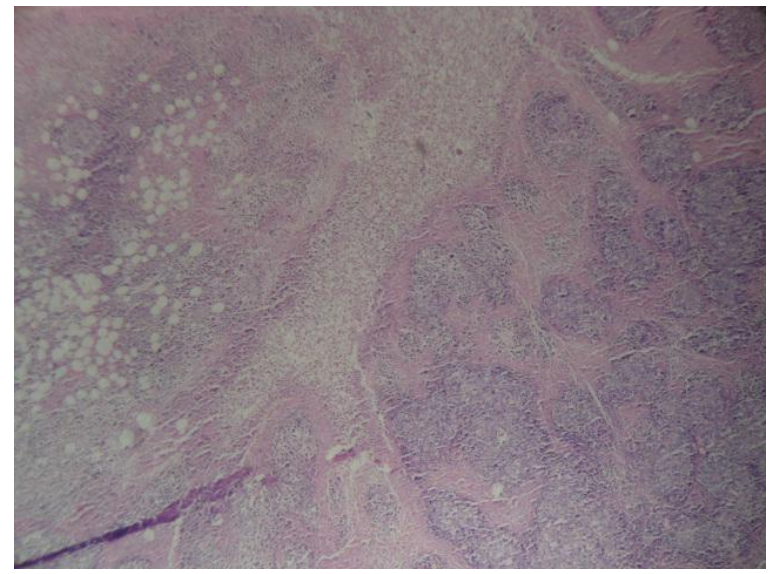

(a)

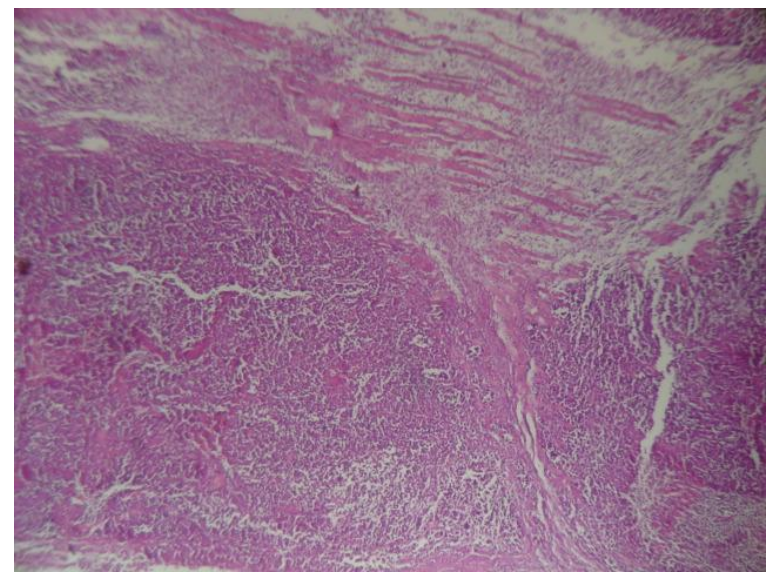

(c)

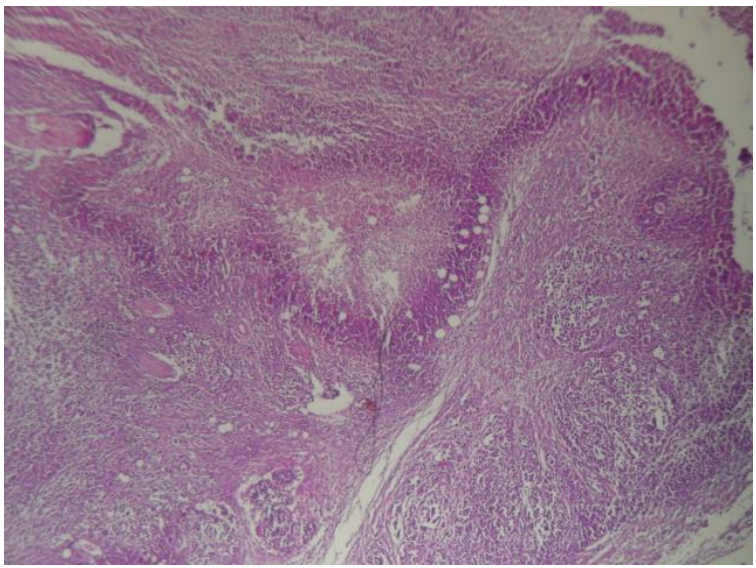

(b)

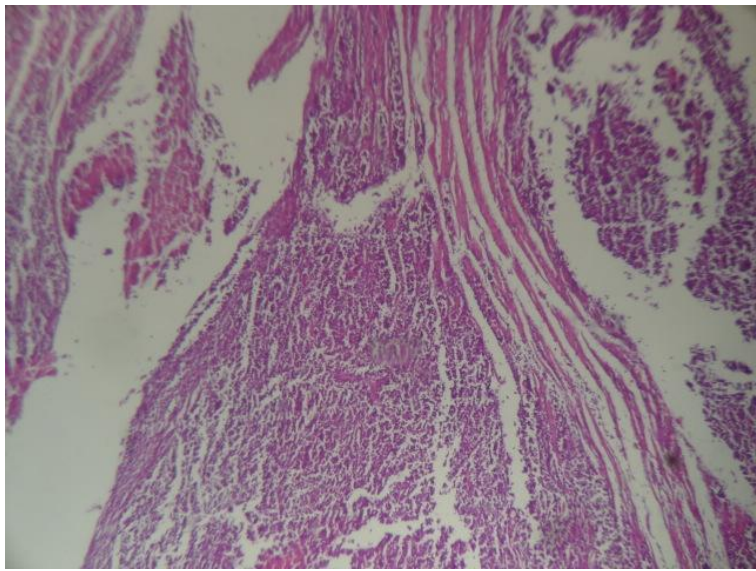

(d)

Fig. (2): Photomicrographs of sections in solid Ehrlich carcinoma (EC) stained by H\&E. 2a, Section in EC; 2b, Section in EC treated by doxorubicin; 2c, Section in EC treated with gallium trichloride; 2d, Section in EC treated with gallium trichloride and doxorubicin.

of intracellular free radicals resulting in oxidative stress causing antioxidant disturbances and acceleration in lipid peroxidation $^{[30-35]}$.

In the present investigations, the administration of $\mathrm{GaCl}_{3}$ alone or combined with Dox showed a marked amelioration in oxidative stress. The results revealed a significant elevation in GPx and catalase activities in heart tissue with a significant decrease in lipid peroxide compared to EC bearing mice group as well as EC+Dox group, This is in harmony with a previous study ${ }^{[36]}$ which reported that, gallium metal upregulate several antioxidant enzymes such as catalase and superoxide dismutase in order to cope with the pro-oxidant properties of this metal. Moreover, $\mathrm{GaCl}_{3}$ at $8 \mathrm{mg} / \mathrm{l}$ decreased the malondialdehyde (MDA) production as reported by ${ }^{[37]}$. Banin et al. ${ }^{[38]}$ recorded that, galliumdesferrioxamine caused a significant reduction, 2.56 fold, in lipid peroxidation in the cat retina, as reflected by levels of malondialdehyde (MDA).

The treatment with $\mathrm{GaCl}_{3}$ and/or dox caused a significant increase in MDA in tumor homogenate accompanied with a marked decrease in antioxidant agents (GPx \& CAT activities). The aforementioned results were in agreement with several studies which mentioned that, Dox was reported to induce ROS generation in various tumor cells ${ }^{[3,39]}$. However, the exact role of ROS in Dox-induced tumor cell killing is still under investigation. Several reports suggest that Dox induced apoptosis plays an important role in its cardiotoxicity that is linked to formation of reactive oxygen species (ROS) derived from redox activation of Dox (39). On the other hand, In this regard, the present results could be appreciated by studies made by Yang and Chitambar ${ }^{[40]}$ who have shown that, $\mathrm{Ga}$ is implicated in intracellular oxidative stress through the generation of reactive oxygen species, with a decrease in the ratio of cellular glutathione reduced form (GSH) on glutathione oxidized form (GSSG). Cells exposed to inorganic gallium salts, such as gallium nitrate, displayed an increased generation of ROS. In addition, it was documented that the new insights into the cellular response to gallium could suggest a model in which the initial exposure of cells to gallium results in an elevation of intracellular ROS which, in turn, invokes a cytoprotective 
response (i.e., an increase in MT2A and HO-1 gene expression) ${ }^{[41]}$. Thus, cell death occurs only when these cytoprotective responses are overwhelmed. These data are consistent with the histopathological results presented in this work.

Cancer cells undergo intensive cell division and need a considerable amount of iron for their development. On the basis of this information, it can be said that the neoplastic process in the organism significantly decreases iron concentration in the serum, probably directing iron to the developing tumor ${ }^{[42]}$. The unique mechanism of antineoplastic action of gallium that involves its ability to target and disrupt tumor cell iron homeostasis sets it apart from other chemotherapeutic drugs. In the present study, treatment of EC bearing mice with $\mathrm{GaCl}_{3}$ either alone or combined with Dox caused a significant decrease of serum iron concentration compared with EC group as well as EC+Dox group. Gallium shares certain similarities with iron that allow it to function as an iron mimetic, bind to iron transport proteins, and thus inhibit iron-dependent cell function ${ }^{[41]}$. Inorganic gallium salts interfere with physiological and intracellular procurement of iron, thus causing its depletion ${ }^{[7]}$.

Doxorubicin is used to treat a wide range of malignant tumors. One limitation of this drug is an associated dose-dependent cardiac toxicity. Olson and Capen ${ }^{[43]}$ first showed cardiac damage in mitochondria and endoplasmic reticulum following ADR treatment using electron microscopy. Although it is perhaps one of the mechanisms of ADR's efficacy, a free radical mediated theory has been proposed to explain ADR-induced cardiac injury. The quinone moiety of this compound is reduced through enzymatic and non-enzymatic mechanisms with concurrent generation of $\mathrm{O}_{2}{ }^{\cdot-}{ }^{[39]}$. Serum CPK, AST and LDH activities are used clinically to evaluate and diagnose cardiac dysfunction and disease. The present data showed that, serum AST, CPK and $\mathrm{LDH}$ activities were significantly elevated in EC and EC+ Dox groups compared to normal control group and these results correlate well with others ${ }^{[39,44]}$.

The data presented here showed that, the administration of $\mathrm{GaCl}_{3}$ alone or combined with Dox showed marked decrease in the activities of serum AST, CPK and LDH compared to both $\mathrm{EC}$ and $\mathrm{EC}+\mathrm{Dox}$ groups. It is suggested that, $\mathrm{GaCl}_{3}$ tends to prevent heart damage, suppresses leakage of enzymes through cellular membranes, preserves the integrity of the plasma membranes and hence restores these enzymes levels. The possible explanation of the improvement of heart marker enzymes in mice treated with $\mathrm{GaCl}_{3}$ and Dox is that; $\mathrm{GaCl}_{3}$ may alters the pharmacokinetics of doxorubicin and therefore decrease its toxicity ${ }^{[45]}$.

In the present study, it has been observed that tumor bearing mice showed a marked elevation in inflammatory markers as TNF- $\alpha$ and IL-10 concentrations in heart and tumor tissues homogenate compared to control group. Cytokines as TNF- $\alpha$ either produced from tumor cells themselves or due to ROS formed during tumor growth have cytotoxic properties that cause tissue injury ${ }^{[46]}$. It is documented that a slight increase in oxidative stress leads to increase in TNF- $\alpha$ level ${ }^{[47]}$.

Cytokines like TNF- $\alpha$ has been recognized as an important host defense cytokine that affects tumor cells. TNF- $\alpha$ plays an inhibitory role in cancer progression, it is rational to hypothesize that blocking its activity may result in increased cancer incidence ${ }^{[\mathbf{4 8 , 4 9 ]}}$. The IL-10 shows its antitumor property by enhancement of the function of natural killer cells and macrophages ${ }^{[50]}$. The stimulation of type 1 helper $\mathrm{T}$ cells (Th1) cytokines along with IL-10 by spleenocytes can be exploited as an adjuvant effect. IL-10 production associated with increased Th1 cytokines explaine the immunostimulatory nature which might involve in indirect tumor regression [51].

The present study revealed that, treatment with $\mathrm{GaCl}_{3}$ alone or combined with Dox showed a significant increase in the levels of TNF- $\alpha$ and IL- 10 in tumor tissue homogenate compared to EC bearing mice group. These observations are well agreed with previous investigations conducted in human leukemic/lymphoma cells which showing that, human leukemia/lymphoma cells exposed to gallium nitrate or gallium maltolate display an initial translocation of inositol phosphotidylserine to the cell surface, an early marker of apoptosis ${ }^{[11]}$.

Based on the results obtained in the present study it could be concluded that, oral administration of $\mathrm{GaCl}_{3}$ synergizes Dox and allows a reduction of the tumor growth in vivo. Due to this effect and the lack of toxicity, $\mathrm{GaCl}_{3}$ may be used as a synergistic chemotherapy with other anticancer drugs which should be further evaluated in a clinical study.

\section{References}

1) Torre, L. A., Bray, F., Siegel, R. L., Ferlay, J., Lortet-Tieulent, J. and Jemal, A. (2015). Global cancer statistics, 2012. CA Cancer J Clin., 65(2): 87108.

2) Alyamkina, E. A., Nikolin, V. P., Popova, N. A., Dolgova, E. V., Proskurina, A. S., Orishchenko, K. E., Efremov, Y. R., Chernykh, E. R., Ostanin, A. A., Sidorov, S. V., Ponomarenko, D. M., Zagrebelniy, S. N., Bogachev, S. S. and Shurdov, (2010). A strategy of tumor treatment in mice with doxorubicin-cyclophosphamide combination based on dendritic cell activation by human double-stranded DNA preparation. Genetic Vaccines and Therapy, 8: $1-10$.

3) Wang, S., Konorev, E. A., Kotamraju, S., Joseph, J., Kalivendi, S. and Kalyanaraman, B. (2004). Doxorubicin induces apoptosis in normal and tumor cells via distinctly different mechanisms. J. Biol. Chem., 279: 25535-25543.

4) Krautwald, S., Ziegler, E., Rolver, L., Linkermann, A., keyser, K. A., Steen, P., Wollert, K. C., Klingebiel, M. K. and Kunzendorf, U. (2010). Blockage of both the extrinsic and intrinsic 
pathways of apoptosis in mice by TAT-crmA, J. Biol. Chem., 285: 19997-20005.

5) Marijke, D. S., Matthias, B., Alfons, V. and Felix, M. M. (2012). Apoptosis imaging to monitor cancer therapy: the road to fast treatment evaluation? Current Pharmaceutical Biotech, 13(4): 571-583.

6) Wang, S., Konorev, E. A., Kotamraju, S., Joseph, J., Kalivendi, S. and Kalyanaraman. B. (2004). Doxorubicin induces apoptosis in normal and tumor cells via distinctly different mechanisms. J. Biol. Chem., 279: 25535-25543.

7) Chitambar, C. R. (2010). Medical applications and toxicities of gallium compounds. Int. J. Environ. Res. Public Health, 7: 2337-2361.

8) Adamson, R. H., Canellos, G. P. and Sieber, S. M. (1975). Studies of antitumor activity of gallium nitrate (NSC-15200) and other group IIIa metal salts. Cancer Chemother, Rep., 59: 599-610.

9) Foster, B. J., Clagett-Carr, K., Hoth, D. and Leyland-Jones, B. (1986). Gallium nitrate: the second metal with clinical activity. Cancer Treat. Rep., 70: 1311-1329.

10) Repetto, G. and del peso, A. (2012). Gallium, indium, and thallium Patty's Toxicology, 257-354.

11) Chitambar, C. R., Purpi, D. P, Jeffrey Woodliff, J., Yang, M. and Wereley, J. P (2007). Development of gallium compounds for treatment of lymphoma: gallium maltolate, a novel hydroxypyrone gallium compound, induces apoptosis and circumvents lymphoma cell resistance to gallium nitrate J. of Pharmcol. And Exp. Ther., 322: 1228-1236.

12) Collery, P., Keppler, B., Madoulet, C. and Desoize, B. (2002). Gallium in cancer treatment. Critical Reviews in Oncology/Hematology, 42: 283296.

13) Chitambar, C. R. and Antholine, W. E. (2013). Iron-Targeting Antitumor Activity of Gallium Compounds and Novel Insights into Triapine-Metal Complexes. Antioxidants \& Redox Signaling, 18(8): 956-972.

14) Akhila, J. S., Deepa, S. and Alwar, M. C. (2007). Acute toxicity studies and determination of median lethal dose. Curr. Sci. 93: 917-920.

15) Narang, A. S. and Desai, D. S. (2009). Anticancer drug development unique aspects of pharmaceutical development. Y. Lu, R.I. Mahato (eds.), Pharmaceutical Perspectives of Cancer Therapeutics, 49-92.

16) Osman, A. El-M., Ahmed, M. M., Khayyal, M. T. and El-Merzabani, M. M. (1993). Hyperthermic potentiation of cisplatin cytotoxicity on solid Ehrlich carcinoma. Tumori, 31(4): 268-272.

17) Rosalki, S. B. (1967). An improved procedure for serum creatine phosphokinase determination. J. Lab. Clin. Med. 69(4): 696-705.

18) Buhl, S. N. and Jackson, K. Y. (1978). Optimal conditions and comparison of lactate dehydrogenase catalysis of the lactate-to-pyruvate and pyruvate-tolactate reactions in human serum at 25,30 , and 37 degrees C. Clin. Chem., 24(5): 828-831.
19) Reitman, S. and Frankel, S. (1957). A colorimetric method for the determination of serum glutamic oxaloacetic and glutamic pyruvic transaminases. Am. J. Clin. Path., 28: 56-63.

20) Dreux, C. (1977). Analyse du serum humain. Ann. Biol. Clin., 35: 275-277.

21) Yoshioka, T. K., Kawada, T., Shimada, and Mori, M. (1979). Lipid peroxidation in maternal and cord blood and protective mechanism against activatedoxygen toxicity in the blood. American Journal of Obstetrics and Gynecology, 135: 372-376.

22) Beutler, E., Duron, O. and Kelly, B. M. (1963). Improved method for the determination of blood glutathione. J Lab Clin Med., 61: 882-888.

23) Gross, R. T., Bracci, R., Rudolph, N., Schroeder, E. and Kochen, J. A. (1967). Hydrogen peroxide toxicity and detoxification in the erytherocytes of newborn infants. Blood., 29(4): 481-493.

24) Drury, A. R. and Wallington, E. A. (1980). Carleton's histological techniques $5^{\text {th }}$ ed. Oxford University press. London. pp., 140.

25) Laginha, K. M., Verwoert, S., Charrois, G. J. and Allen, T. M. (2005). Determination of doxorubicin levels in whole tumor and tumor nuclei in murine breast tumors. Clin Cancer Res., 11: 6944-6949.

26) Minat, L., Antonini. V., Dalla Serra, M., Speranza, G., Enrichi, F. and Riello, P. (2013). pH-activated doxorubicin release from polyelectrolyte complex layer coated mesoporous silica nanoparticles. Microporous and Mesoporous Materials, 180: 86-91.

27) Oh, H. J., Jang, H. R., Jung, K.Y. and Kim, J. H. (2013). Evaluation of surface area of mesoporous silica adsorbents for separation and purification of paclitaxel. Microporous and Mesoporous Materials, 180: 109-113.

28) Jakupec, M. A. and Keppler, B. K. (2004). Gallium in cancer treatment, Curr. Top. Med. Chem., 4(15): 1575-1583.

29) Rajendran, P., Nandakumar, N., Rengarajan, T., Palaniswami, R., Gnanadhas, E. N., Lakshminarasaiah, U., Gopas, J. and Nishigaki, I. (2014). Antioxidants and human diseases. J. Clin. Chim. Acta., 25; 436C:332-347.

30) Sabina, E. P., Rasool, M., Vedi, M., Navaneethan, D., Ravichander, M., Parthasarthy, P. and Thella, S. R. (2013). Hepatoprotective and antioxidant potential of withania somnifera against paracetamolinduced liver damage in rats. Int J Pharm. Pharm. Sci., 5(2): 648-651.

31) Bauer, G. (2014). Targeting extracellular ROS signaling of tumour cells. J. Anticancer Res., 34(4): 1467-1482.

32) Huo, W., Li, Z. M., Pan, X. Y., Bao, Y. M. and An, L. J. (2014). Antioxidant Enzyme Levels in Pathogenesis of Oral Squamous Cell Carcinoma (OSCC). J. Drug. Res., 64(11): 629-632.

33) Okuno, T., Honda, E., Arakawa, T., Ogino, H. and Ueno, H. (2014). Glutathione-dependent cell cycle G1 arrest and apoptosis induction in human lung cancer A549 cells caused by methylseleninic 
acid: comparison with sodium selenite. J. Biol. Pharm. Bull., 37(11): 1831-1837.

34) Wang, C., Yu, J., Wang, H., Zhang, J. and Wu, N. (2014). Lipid Peroxidation and Altered Antioxidant Status in Breast Adenocarcinoma Patients. J. Drug. Res., 64(12): 690-692.

35) Patra, S., Muthuraman, M. S., Prabhu, R., Priyadharshini, R. and Parthiban, S. (2015). Evaluation of Antitumor and Antioxidant Activity of Sargassum tenerrimum against Ehrlich Ascites Carcinoma in Mice. Asian Pacific Journal of Cancer Prevention, 16: 915-921.

36) Singh, R., Beriault, R., Middaugh, J., Hamel, R., Chenier, D., Appanna, V. D. and Kalyuzhnyi, S. (2005). Aluminum-tolerant Pseudomonas fluorescens: ROS toxicity and enhanced NADPH production. Extremophiles, 9: 367-373.

37) Leperre, A., Millart, H., Prévost, A., Kantelip, J. P., Lamiable, D. and Collery, P. (1994). Gallium chloride effects on neonatal rat heart cells in culture, in standard and oxidative conditions. Fundamental \& Clinical Pharmacology 8: 563-569.

38) Banin, E., Berenshtein, E., Kitrossky, N., Pe'er, J. and Chevion, M. (2000). Gallium-desferrioxamine protects the cat retina against injury after ischemia and reperfusion. Free Radic Biol Med., 28(3): 315323.

39) Cole, M. P., Chaiswing, L., Oberley, T. D., Edelmann, S. E., Piascik, M. T., Lin, S. M., Kiningham, K. K. and St. Clair, D. K. (2006). The protective roles of nitric oxide and superoxide dismutase in adriamycin-induced cardiotoxicity. Cardiovascular Res., 69(1): 186-197.

40) Yang, M. and Chitambar, C. R. (2008). Role of oxidative stress in the induction of metallothionein$2 \mathrm{~A}$ and heme oxygenase-1 gene expression by the antineoplastic agent gallium nitrate in human lymphoma cells. Free Radic Biol Med., 45: 763-772.

41) Chitambar, C. R. (2012). Gallium-containing anticancer compounds. Future Med. Chem., 4(10): 1257-1272.
42) Gurzau, E. S., Neagu, C. and Gurzau, A. E. (2003). Essential metals-case study on iron. Ecotoxicol Environ Safe., 56(1): 190-200.

43) Olson, H. M. and Capen, C. C. (1977). Subacute cardiotoxicity of adriamycin in the rat. Lab Invest., 37: 386-394.

44) Kandil, E. and Abdel Aziz, N. (2015). Synergistic Efficacy of $\gamma$-radiation together with Gallium Trichloride and/ or Doxorubicin against Ehrlich Carcinoma in Female Mice. Tumor Biology, 37(2): 1825-1834.

45) Sridhar, R., Dwivedi, C., Anderson, J., Baker, P. B., Sharma, H. M., Desai, P. and Engineer, F. N. (1992). Effects of verapamil on the acute toxicity of doxorubicin in vivo. JNCI J Natl Cancer Inst., 84(21), 1653-1660.

46) Lehmann, V., Freudenberg, M. A. and Galanos, C. (1987). Lethal toxicity of lipopolysaccharide and tumor necrosis factor in normal and Dgalactosamine-treated mice. J. Exp. Med., 165: $657-$ 663.

47) Gupta, A., Sharma, S., Kaur, I. and Chopra, K. (2009). Renoprotective effects of sesamol in ferric nitrilotriacetate-induced oxidative renal injury in rats. Basic \& Clinical Pharmacol. \& Toxicol., 104(4): 316-321.

48) Bratcher, J. M. and Korelitz, B. I. (2006). Toxicity of infliximab in the course of treatment of Crohn's disease. Expert Opin. Drug Saf., 5: 9-16.

49) Liu, C., Yin, L., Chen, J. and Chen J. (2014). The apoptotic effect of shikonin on human papillary thyroid carcinoma cells through mitochondrial pathway. Tumor Biol., 35: 1791-1798.

50) Mocellin, S., Panelli, M. C., Wang, E., Nagorsen, D. and Marincola, F. M. (2003). The dual role of IL-10. Trends in immunol., 24: 36-43.

51) Bhutia, S. K., Mallick, S. K., Maiti, S. and Maiti, T. K. (2008). Inhibitory effect of Abrus abrin-derived peptide fraction against Dalton's lymphoma ascites model. Phytomedicine, 16(4): 377-85. 